\title{
EVALUATION OF PHYSICAL STABILITY AND DRUG CONTENT OF ZOLEDRONATE BISPHOSPHONATE GEL
}

\author{
Fransiska Monika ${ }^{1}$, Muhamad Sahlan ${ }^{2,3}$, Krisnawati' ${ }^{1}$ Diah Kartika Pratamii ${ }^{4}$, Retno Widayati ${ }^{1}$ \\ 'Department of Orthodontics, Faculty of Dentistry, Universitas Indonesia, Jakarta, Indonesia \\ ${ }^{2}$ Department of Chemical Engineering, Faculty of Engineering, Universitas Indonesia, West Java, Indonesia \\ ${ }^{3}$ Research Center of Biomedical Engineering, Faculty of Engineering, Universitas Indonesia, West Java, Indonesia \\ "Faculty of Pharmacy, Universitas Indonesia, West Java, Indonesia
}

\begin{abstract}
INTRODUCTION: The gel emulsion form of zoledronate bisphosphonate has been proven to increase the number of osteoclasts via apoptosis when applied topically. The gel form is commonly used for topical application in the oral cavity.

Овјестіves: We aimed to evaluate the physical stability of zoledronate bisphosphonate in its gel form to assess its suitability for clinical application.

MATERIAL AND METHODs: The gel formulation was prepared using carboxymethylcellulose, glycerine, and sodium benzoate in a dosage form of $40 \mu \mathrm{g}$ of zoledronate per $25 \mathrm{mg}$ of the gel. The prepared gels were stored at $25^{\circ} \mathrm{C}$ and $40^{\circ} \mathrm{C}$ for 28 days and evaluated for viscosity, $\mathrm{pH}$ value, spreadability, adhesive strength, and drug content on days 1 , 7,14 , and 28 of incubation.

Results: Throughout the study, at $40^{\circ} \mathrm{C}$ of storage, the gel demonstrated significantly increasing viscosity and adhesive strength, but decreasing spreadability. However, the $\mathrm{pH}$ and drug content decreased at $25^{\circ} \mathrm{C}$ and $40^{\circ} \mathrm{C}$.

ConCLusion: Zoledronate bisphosphonate gel showed stability in physical characteristics and drug content when stored at $25^{\circ} \mathrm{C}$ for 28 days.
\end{abstract}

KEY WORDS: zoledronate, drug stability, orthodontic tooth movement.

J Stoma 2018; 71, 5: 387-391

DOI: https://doi.org/10.5114/jos.2018.84650

\section{INTRODUCTION}

In orthodontic treatment, undesirable tooth movement of the anchorage unit and the relapse of moved teeth to their original positions are important problems $[1,2]$. Various mechanical appliances have been used to reinforce the anchorage in such cases, such as the transpalatal arch, Nance holding arch, temporary anchorage device, and headgear. However, anchorage loss and other side-effects continue to occur, thereby compromising the treatment outcomes [3-5]. Besides the mechanical appliances, studies have shown that undesirable tooth movement could be prevented by blocking the bone resorption with a pharmacological agent [6].

Bisphosphonates are widely used as drugs to treat osteoporosis and other bone diseases. Past studies have shown that the administration of bisphosphonate can increase the amount of osteoclast apoptosis and thereby inhibit tooth movement $[6,7]$. There are two types

\section{JOURNAL OF} STOMATOLOGY CZASOPISMO STOMATOLOGICZNE

AdDRESS FOR CORRESPONDENCE: Dr. drg. Retno Widayati, Sp.Ort(K), Faculty of Dentistry, Universitas Indonesia, Jakarta, Indonesia, 10430, phone: +62 2131930270 , e-mail: widayati22@yahoo.com 
of bisphosphonates, which are distinguished by the nature of the side chains attached to the carbon atom. Bisphosphonates that contain a nitrogen atom $(\mathrm{N}$-containing bisphosphonates) possess a higher potency than those without a nitrogen atom (non- $N$-containing bisphosphonates). The $\mathrm{N}$-containing bisphosphonates inhibit the farnesyl pyrophosphate synthase enzyme, which in turn inhibits the prenylation of a small protein called guanosine triphosphate in osteoclasts. This event eventually leads to osteoclast apoptosis [8, 9]. Zoledronate is an $\mathrm{N}$-containing bisphosphonate and the most potent inhibitor of the hydroxyapatite growth rate [8].

Past studies have shown that the administration of bisphosphonates can inhibit orthodontic tooth movement in animal models [10-12]. It has been suggested that the administration of zoledronate bisphosphonate in gel emulsion can also increase the amount of osteoclast apoptosis. Topical application is less painful than that through injection [13]. Topical application in the gel form has been widely used in the oral cavity, such as in the treatment of periodontitis, ulceration, and oral candidiasis [14-16]. In comparison with ointments and cream bases, gels possess a higher water content, thereby permitting greater dissolution of drugs [17].

Stability testing of drug products is performed at various stages of product development. The purpose of pharmaceutical stability testing is to ensure that the products retain acceptable quality for a certain period of time to maintain the efficacy and safety of the drugs [18]. The present study aimed to evaluate the physical stability and drug content of zoledronate bisphosphonate in the gel form to evaluate one of the prerequisites in developing a new drug product.

\section{MATERIAL AND METHODS}

Zoledronate powder was purchased from SigmaAldrich (Singapore). Carboxymethylcellulose (CMC) and sodium benzoate were purchased from Harum Kimia CV (Jakarta, Indonesia). Glycerine was purchased from Indogen Ltd. (Jakarta, Indonesia). Distilled water was used throughout the study.

\section{GEL PREPARATION}

Zoledronate powder was dissolved in phosphatebuffered saline in a $1: 1$ ratio (w/v). CMC, glycerine, sodium benzoate, and distilled water were mixed with constant stirring in a glass beaker until a homogeneous solution was formed. The resultant gel was mixed with zoledronate solvent using a mixer in a dosage form of $40 \mu \mathrm{g}$ zoledronate per $25 \mathrm{mg}$ of the gel.

\section{GEL EVALUATION}

The following parameters were used to evaluate the gel properties:

1. Organoleptic test: The prepared zoledronate bisphosphonate gel formulations were inspected visually for color, odor, taste, consistency, and homogeneity.

2. Viscosity: Viscosity measurement was performed using a viscometer (Brookfield, USA) with spindle 7. The corresponding dial reading was noted at each speed.

3. $\mathrm{pH}$ value: The $\mathrm{pH}$ value of the gel was measured using a digital $\mathrm{pH}$ meter (Eutech Instruments, USA) by dissolving $1 \mathrm{~g}$ of gel in $100 \mathrm{ml}$ of distilled water.

4. Spreadability: The spreadability was evaluated by placing the gel between 2 glass plates, followed by putting a stone weighing $100 \mathrm{~g}$ on top of the glass plate for $1 \mathrm{~min}$. The diameter of the spread gel was then measured.

5. Adhesive strength: Adhesive strength was determined by placing the gel between 2 glass plates, followed by placing a stone weighing $250 \mathrm{~g}$ on top of the glass plate for $5 \mathrm{~min}$. The glass plates were placed in the apparatus, and then a weight of $80 \mathrm{~g}$ was added. The time required to detach the glass plates from each other was recorded.

6. Drug content: The drug content of the gel was measured with an ultraviolet-visible spectrophotometer (Spectroquant Pharo 300, Germany). The gel (100 mg) was diluted to $5 \mathrm{ml}$ with distilled water. A volume of $1 \mathrm{ml}$ of this solution was further diluted to make an amount of $5 \mathrm{ml}$ with distilled water. Then, the solution was placed in a cuvette and absorbance was measured at $210 \mathrm{~nm}$.

7. Stability studies: The prepared gels were packed in Eppendorf tubes and subjected to stability studies at $25^{\circ} \mathrm{C}$ and $40^{\circ} \mathrm{C}$ for 28 days. The samples were evaluated on days $1,7,14$, and 28 for viscosity, $\mathrm{pH}$ value, spreadability, adhesive strength, and drug content.

\section{STATISTICAL ANALYSIS}

The data were analyzed using the independent $t$-test to determine the differences in the outcomes between storage at $25^{\circ} \mathrm{C}$ and $40^{\circ} \mathrm{C}$. Repeated measure ANOVA was used to calculate the significant differences among the outcomes on days $1,7,14$, and 28. Statistical calculations were performed using SPSS 23.0 version.

\section{RESULTS}

Zoledronate bisphosphonate gel was evaluated for physical appearance, viscosity, spreadability, adhesive strength, $\mathrm{pH}$, and drug content at $25^{\circ} \mathrm{C}$ and $40^{\circ} \mathrm{C}$ after 28 days of storage. The results of the physical appearance test are given in Table 1 . The standard calibration curve of zoledronate for the spectrophotometry test is shown in Figure 1. 
TABLE 1. Physical appearance of zoledronate bisphosphonate gel

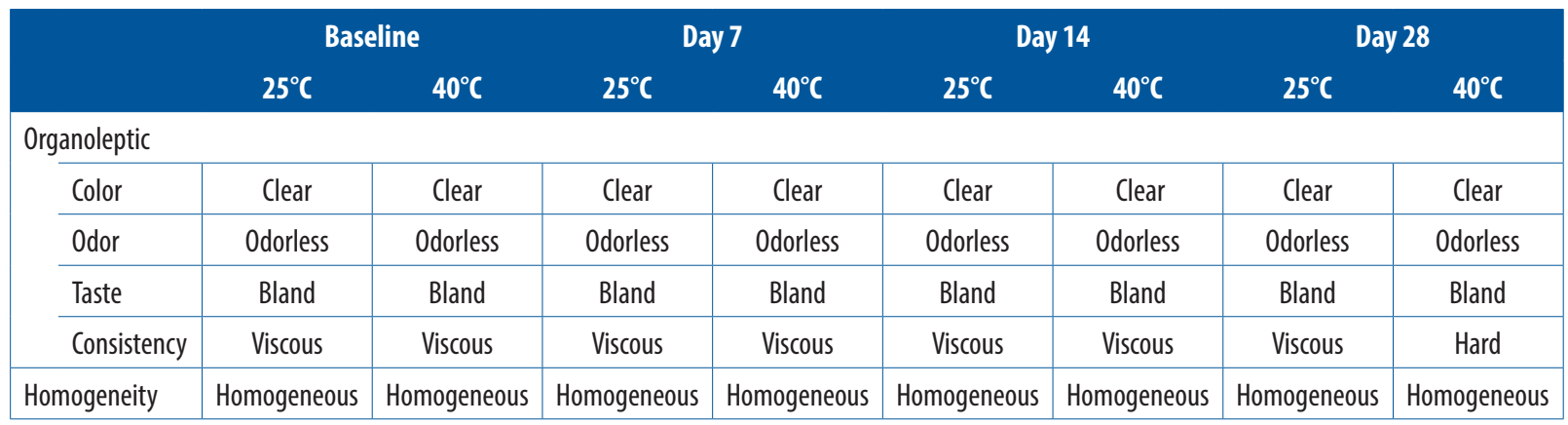

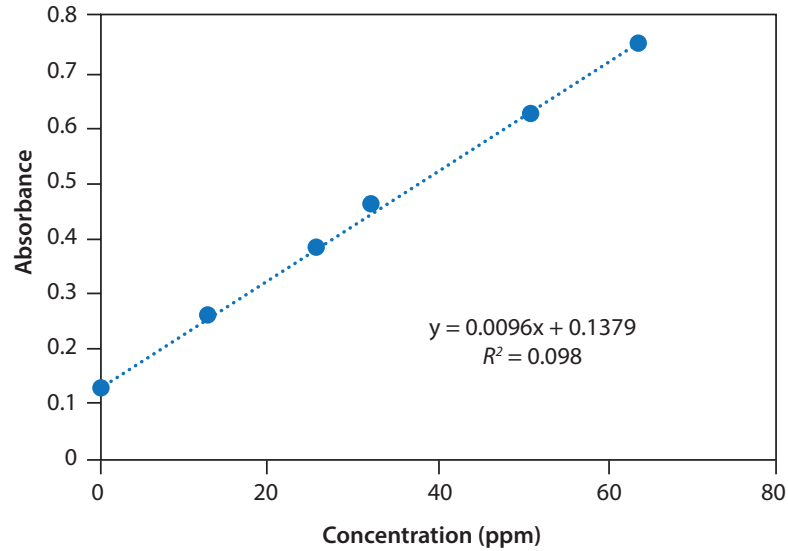

FIGURE 1. Standard calibration curve of zoledronate

The changes in viscosity of the gel at $25^{\circ} \mathrm{C}$ and $40^{\circ} \mathrm{C}$ are illustrated in Figure 2. The viscosity of the gel increased significantly during storage at $40^{\circ} \mathrm{C}$ over 14 days. Figure 3 represents the mean spreadability of the gel at $25^{\circ} \mathrm{C}$ and $40^{\circ} \mathrm{C}$ throughout the study. Statistical analysis revealed a significant difference in the spreadability values before and after storage at $40^{\circ} \mathrm{C}$. Figure 4 shows the mean adhesive strength of the gel at $25^{\circ} \mathrm{C}$ and $40^{\circ} \mathrm{C}$ for different periods of time. Changes in the adhesive strength were found to significantly increase at storage temperature of $40^{\circ} \mathrm{C}$.

The mean $\mathrm{pH}$ values of all prepared gels are shown in Figure 5. From the statistical analysis, the $\mathrm{pH}$ value significantly decreased at $25^{\circ} \mathrm{C}$ and $40^{\circ} \mathrm{C}$. The drug content also showed significant changes at $25^{\circ} \mathrm{C}$ and $40^{\circ} \mathrm{C}$ throughout the study, as shown in Figure 6.

\section{DISCUSSION}

In the present study, we evaluated the physical stability and drug content of zoledronate bisphosphonate gel as one of the prerequisites for developing a new drug product. The physical appearances of the prepared gels during storage at $25^{\circ} \mathrm{C}$ and $40^{\circ} \mathrm{C}$ for 28 days were as follows: clear in color, bland in taste, odorless, and homogeneous. However, the consistency of the gel hardened

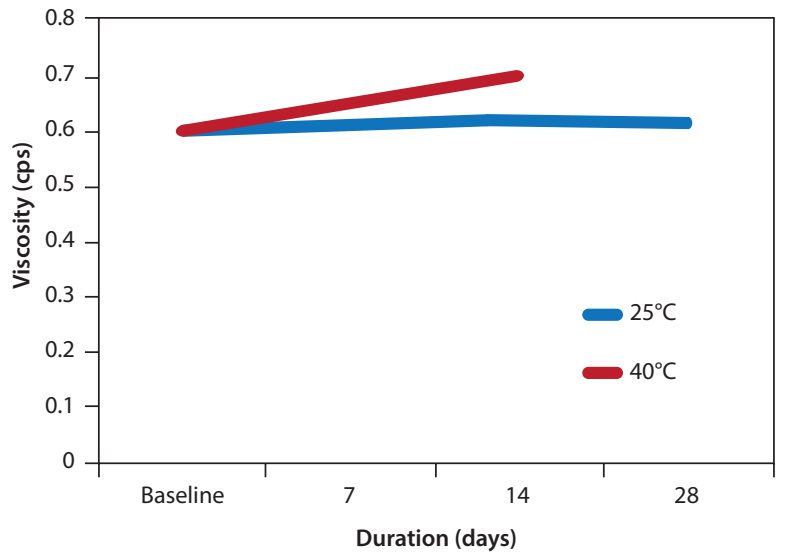

FIGURE 2. Mean viscosity of zoledronate bisphosphonate gel at $25^{\circ} \mathrm{C}$ and $40^{\circ} \mathrm{C}$ for different time periods. Changes in viscosity over 14 days at $40^{\circ} \mathrm{C}$ were statistically significant $(p<0.05)$

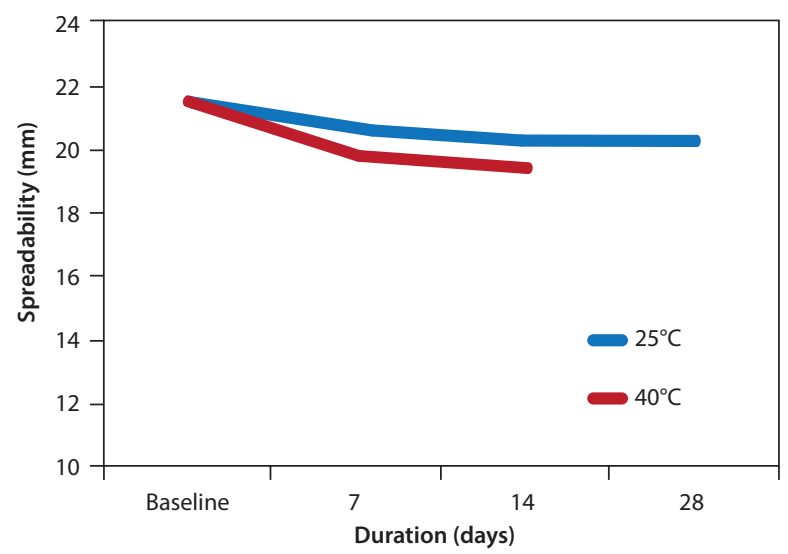

FIGURE 3. Mean spreadability of zoledronate bisphosphonate gel at $25^{\circ} \mathrm{C}$ and $40^{\circ} \mathrm{C}$ for different time periods. Changes in the spreadability value over 14 days at $40^{\circ} \mathrm{C}$ were statistically significant $(p<0.05)$

on day 28 at $40^{\circ} \mathrm{C}$; therefore, the stability test could not be performed.

This study showed that the viscosity value increased throughout the study period, but it was statistically 


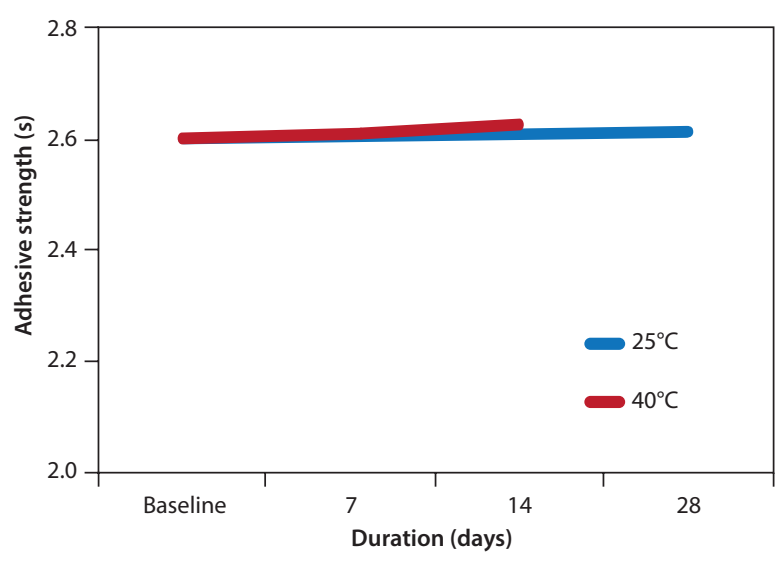

FIGURE 4. Mean adhesive strength of zoledronate bisphosphonate gel at $25^{\circ} \mathrm{C}$ and $40^{\circ} \mathrm{C}$ for different time periods. Changes in the adhesive strength over 14 days at $40^{\circ} \mathrm{C}$ were statistically significant $(p<0.05)$

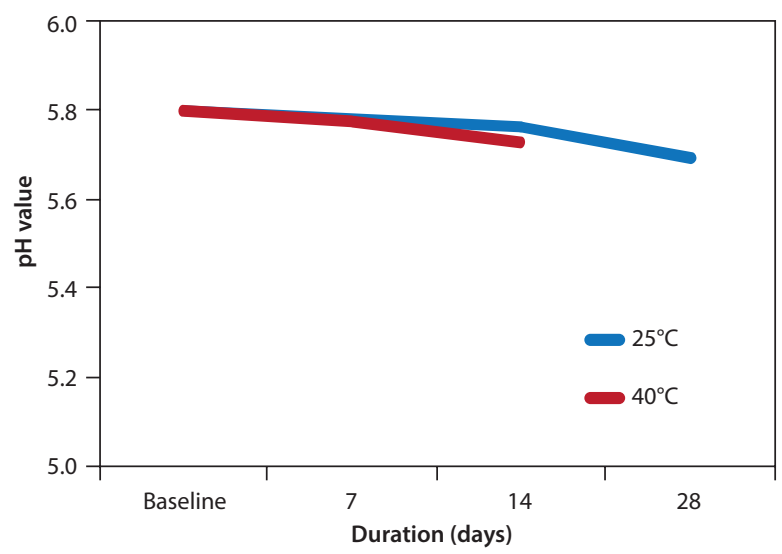

FIGURE 5. Mean $\mathrm{pH}$ value of zoledronate bisphosphonate gel at $25^{\circ} \mathrm{C}$ and $40^{\circ} \mathrm{C}$ for different time periods. Changes in the $\mathrm{pH}$ value at $25^{\circ} \mathrm{C}$ over 28 days and at $40^{\circ} \mathrm{C}$ over 14 days were statistically significant $(p<0.05)$

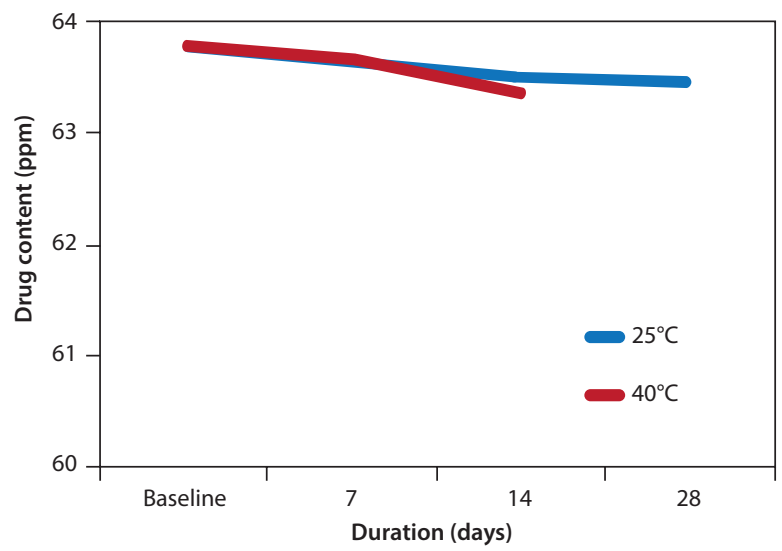

FIGURE 6. Mean drug content of zoledronate bisphosphonate gel at $25^{\circ} \mathrm{C}$ and $40^{\circ} \mathrm{C}$ for different time periods. Changes in the drug content at $25^{\circ} \mathrm{C}$ over 28 days and at $40^{\circ} \mathrm{C}$ over 14 days were statistically significant $(p<0.05)$ significant at $40^{\circ} \mathrm{C}$. This finding indicates that an increase in the temperature increased the viscosity. The rise in temperature decreases the moisture content. Gels with lower moisture contents were firmer than those with higher moisture contents [19]. The influence of temperature on the cellulose-based gel viscosity in this study was also similar to that reported by other studies. Ghannam et al. reported that the higher the CMC concentration in the solution was, the lower was the flow behavior in$\operatorname{dex}[20]$. Owen et al. also reported an increase in viscosity of cellulose-based gel with increasing temperature [21].

In this study, the gel's spreadability and adhesive strength at $25^{\circ} \mathrm{C}$ were stable over 28 days. The spreadability was found to decrease significantly at $40^{\circ} \mathrm{C}$ over a period of 14 days. However, the adhesive strength was found to increase significantly at $40^{\circ} \mathrm{C}$ over a period of 14 days. This finding is consistent with that of the study by Riski et al. showing that spreadability has a nonlinear relationship with viscosity, whereas adhesive strength has a linear relationship with viscosity. The higher the viscosity value is, the lower is the spreadability but the higher is the adhesive strength [22]. In this study, the range of the spreadability value was $19.5-21.5 \mathrm{~cm}$ and that of the adhesive strength value was $2.60-2.63 \mathrm{~s}$. These values were below the standard values for topical application, which are approximately $5-7 \mathrm{~cm}$ for spreadability and $\geq 4$ s for adhesive strength [23]. However, our findings are still acceptable for topical drug application in the oral cavity, which does not need a large area and a long time for application to prevent being carried away and removed by the saliva. CMC possesses a good adhesive property with biological substrates, such as the oral cavity [24].

Zoledronate monohydrate is designated chemically as (1-hydroxy-2-imidazole-1-Cyl-phosphonoethyl) phosphonic acid, and the $\mathrm{pH}$ of a $0.7 \%$ solution of zoledronic acid in water is approximately 2.0 [25]. In the present study, CMC, glycerine, and distilled water, which have more basic $\mathrm{pH}$, were added and mixed with zoledronate to make the final $\mathrm{pH}$ of the gel to approximately 5.8. Throughout the study, the $\mathrm{pH}$ value decreased at $25^{\circ} \mathrm{C}$ and $40^{\circ} \mathrm{C}$, with the final $\mathrm{pH}$ of 5.69 at $25^{\circ} \mathrm{C}$. The oral cavity uses the salivary system as a buffer, which maintains the $\mathrm{pH}$ of 6.0-7.5. Therefore, this value was close to that of the oral mucosal $\mathrm{pH}$ and hence acceptable. The decrease in the $\mathrm{pH}$ value was similar to that in other studies and could have been caused by hydrolysis, oxidation, light, microorganisms, and chemical reaction between $\mathrm{CO}_{2}$ and the water phase in the gel during storage [26].

The zoledronate dosage in this study was based on the previous research by Anggraini, which was $40 \mu \mathrm{g}$ of zoledronate per $25 \mathrm{mg}$ of gel or $0.16 \%$ of zoledronate in the gel [13]. When converted to the unit parts per million (ppm), the drug content of zoledronate was $16,000 \mathrm{ppm}$. The zoledronate bisphosphonate gel was diluted 25 -fold to fit the range of the zoledronate standard calibration curve, achieving the final concentra- 
tion of approximately $64 \mathrm{ppm}$. Our results revealed that the concentration of zoledronate in the gel on day 1 was $63.8 \mathrm{ppm}$ as per the spectrophotometry test. The drug content decreased at $25^{\circ} \mathrm{C}$ and at $40^{\circ} \mathrm{C}$ throughout the study, with a more significant decrease at $40^{\circ} \mathrm{C}$. The decreasing value was in accordance with the bisphosphonate drug half-life, which is up to 10 years. The rising temperature can also accelerate the chemical degradation of a substance [6].

In this study, the gels were packed in polypropylene Eppendorf tubes. The hardened consistency of gel at $40^{\circ} \mathrm{C}$ on day 28 indicates that the tubes could not protect the gels from the rising temperature. Further studies are needed on drug packaging along with long-term drug stability testing for better clarification.

Zoledronate is a third-generation bisphosphonate that possesses the potential to inhibit bone resorption. Zoledronate bisphosphonate in the gel emulsion form can increase the amount of osteoclast apoptosis and hence facilitate bone remodeling to modify orthodontic tooth movement [13]. Osteoclast apoptosis can inhibit bone resorption and decrease the rate of alveolar bone remodeling during orthodontic tooth movement. Bisphosphonate has been recommended as a potential pharmacological agent for orthodontic anchorage reinforcement [6]. Our findings confirm that zoledronate bisphosphonate in the gel form possesses good stability at $25^{\circ} \mathrm{C}$ and therefore has potential in topical drug application for the oral cavity.

\section{CONCLUSIONS}

In conclusion, zoledronate bisphosphonate gel is stable in its physical appearance, viscosity, spreadability, adhesive strength, $\mathrm{pH}$, and drug content at $25^{\circ} \mathrm{C}$ after 28 days of storage, suggesting its potential for use in topical drug preparation.

\section{ACKNOWLEDGMENT}

This research was funded by a Universitas Indonesia PITTA Grant (International Indexed Publication for UI Student's Final) 2018. We also would like to thank the Research Center for Biomedical Engineering and Laboratory of Pharmaceutical Formulation and Development Universitas Indonesia for providing facilities.

\section{CONFLICT OF INTEREST}

The authors declare no potential conflicts of interest with respect to the research, authorship, and/or publication of this article.

\section{References}

1. Haque S, Sandler PJ, Cobourne MT, et al. A retrospective study comparing the loss of anchorage following the extraction of maxil- lary first or second premolars during orthodontic treatment with fixed appliances in adolescent patients. J Orthod 2017; 44: 268-276.

2. Su H, Han B, Li S, et al. Factors predisposing to maxillary anchorage loss: a retrospective study of 1403 cases. PLoS One 2014; 9: e109561.

3. Mitchell L. Anchorage planning. In: An Introduction to Orthodontics. $4^{\text {th }}$ ed. Oxford University Press, Oxford 2013; 180-190.

4. Cobourne MT, DiBiase AT. Contemporary fixed appliances. In: Handbook of Orthodontics. $2^{\text {nd }}$ ed. Elsevier 2015; 291-326.

5. Proffit W. Contemporary orthodontics. In: Contemporary Orthodontics. $5^{\text {th }}$ ed. Mosby 2013; 281-282.

6. Krishnan V, Davidovitch Z. The effect of drugs and diet on orthodontic tooth movement. In: Biological Mechanisms of Tooth Movement. $2^{\text {nd }}$ ed. Wiley Blackwell, Oxford 2015; 173-187.

7. Lotwala RB, Greenlee GM, Ott SM, et al. Bisphosphonates as a risk factor for adverse orthodontic outcomes: a retrospective cohort study. Am J Orthod Dentofac Orthop 2008; 142: 625-634.e3.

8. Papapoulos SE. Bisphosphonates: how do they work? Best Pract Res Clin Endocrinol Metab 2008; 22: 831-847.

9. Karras JC, Miller JR, Hodges JS, et al. Effect of alendronate on orthodontic tooth movement in rats. Am J Orthod Dentofac Orthop 2009; 136: 843-847.

10. Sirisoontorn I, Hotokezaka H, Hashimoto M, et al. Orthodontic tooth movement and root resorption in ovariectomized rats treated by systemic administration of zoledronic acid. Am J Orthod Dentofac Orthop 2012; 141: 563-573.

11. Venkataramana V, Chidambaram S, Reddy BV, et al. Impact of bisphosphonate on orthodontic tooth movement and osteoclastic count: an animal study. J Int Oral Health 2014; 6: 1-8.

12. Liu L, Igarashi $\mathrm{K}$, Haruyama $\mathrm{N}$, et al. Effects of local administration of clodronate on orthodontic tooth movement and root resorption in rats. Eur J Orthod 2004; 26: 469-473.

13. Anggraini D, Widayati R, Purwaningsih EH, Jusuf AA. Exposure of gel emulsion zoledronate bisphosphonate olive oil increase osteoclast apoptosis. J Int Dent Med Res 2016; 9: 382-386.

14. Zhang L, Fu J, Hua H, Yan Z. Efficacy and safety of miconazole for oral candidiasis: a systematic review and meta-analysis. Oral Dis 2016; 22: 185-195.

15. Hosadurga RR, Rao SN, Jose J, et al. Evaluation of the efficacy of $2 \%$ curcumin gel in the treatment of experimental periodontitis. Pharmacognosy Res 2014; 6: 326-333.

16. Pertiwi RD, Kristanto J, Praptiwi GA. Staphylococcus aureus antibacterial activity test of gel formulation for ulceration from Abrus precatorius Linn. J Ilm Manuntung 2016; 2: 239-247.

17. Khullar R, Kumar D, Seth N, Saini S. Formulation and evaluation of mefenamic acid emulgel for topical delivery. Saudi Pharm J 2012; 20: 63-67.

18. Matthews BR. Regulatory aspects of stability testing in Europe. Drug Dev Ind Pharm 1999; 25: 831-856.

19. Lee SK, Anema S, Klostermeyer H. The influence of moisture content on the rheological properties of processed cheese spreads. Int J Food Sci Technol 2004; 39: 763-771.

20. Ghannam MT, Esmail MN. Rheological properties of carboxymethyl cellulose. J Appl Polym Sci 1997; 64: 289-301.

21. Owen DH, Peters JJ, Lavine ML, Katz DF. Effect of temperature and $\mathrm{pH}$ on contraceptive gel viscosity. Contraception 2003; 67: 57-64.

22. Riski R, Umar AH, Rismadani: Antiinflammatory emulgel formulation from Javanese ginger extract (Curcuma xanthorrhiza Roxb). J Pharm Med Sci 2016; 1: 1-4.

23. Sari DK, Sugihartini N, Yuwono T. Iritation test \& physical properties evaluation of clove flower essential oil emulgel. Pharmaciana 2015; 5: 115-120.

24. Jones DS, Woolfson AD, Brown AF. Textural, viscoelastic and mucoadhesive properties of pharmaceutical gels composed of cellulose polymers. Int J Pharm 1997; 151: 223-233.

25. Association F \& D. Zoledronate Acid Injection. Schaumburg $2016 ; 12$.

26. Rathbone MJ, Pather I, Şenel S. Overview of oral mucosal delivery. In: Oral Mucosal Drug Delivery and Therapy. Springer 2015; 17-23. 